\title{
Surfactant Protein A Deficiency
}

National Cancer Institute

\section{Source}

National Cancer Institute. Surfactant Protein A Deficiency. NCI Thesaurus. Code C99072.

Deficiency of surfactant protein A. When present in normal amounts, this protein protects the lungs against a variety of bacteria, viruses, and fungi. 